\title{
The Bank Lending Channel of Monetary Policy and its Macroeconomic Effects: Evidence from a Sample of Selected Euro Area Countries
}

\author{
Silvo Dajcman \\ University of Maribor \\ Razlagova 14, 2000 Maribor, Slovenia \\ E-mail.silvo.dajcman@uni-mb.si \\ cross $^{r e f}$ http://dx.doi.org/10.5755/j01.ee.27.2.12647
}

\begin{abstract}
Monetary policy measures can affect the supply and demand for bank loans through several transmission mechanisms: the credit channel (that encompasses the bank lending channel and the balance sheet channel), the bank capital channel, and the risk-taking channel. This paper aims to provide evidence on whether the bank landing channel in the selected euro area countries as a whole is operational. Unlike the existent studies we test for differences of the bank lending channel relevance for the large and the small and medium-sized enterprises (SMEs). We apply a macro identification strategy to identify loan supply shocks attributable to the banks' balance sheet constraints and use them in a typical monetary policy VAR model to verify the existence of the bank lending channel. Additionally, we provide evidence on how the shocks in loan activity affect output and inflation.

The analysis of impulse responses reveals that a negative shock (an increase in the policy rate) leads to a significant increase in credit standards for large enterprises as well as the SMEs. This implies that the restrictive monetary policy shock increases banks' balance sheet constraints and that the banks in the short run respond by tightening credit standards for enterprises. Tightening credit standards shock in turn negatively impacts the growth of business loans. The empirical results thus provide evidence that the bank lending channel is operational. A negative shock to the credit standards reduces output in the short run, yet no significant impact on inflation can be observed. When banks unexpectedly tighten credit standards for SMEs the monetary policy (European central bank) seems to respond in a more pronounced manner (by reducing monetary policy rate more) than when banks tighten credit standards for large enterprises.
\end{abstract}

Keywords: Banks Loans, Credit Standards for Loans to Enterprises, Monetary Policy, Transmission Channel, Small- and Medium-Sized Enterprises, Panel VAR.

\section{Introduction}

Bank loans are imperfect substitutes for other funding sources of enterprises, especially in the European bankbased financial systems in which enterprises, especially small- and medium-sized enterprises (SMEs), predominately turn to banks for their external financing (see for instance ECB (2014)). The slowdown in credit activity following the global financial crisis in the euro area observed in recent years has triggered an increased academic attention (see Peek and Rosengreen (2013) for review of studies) and monetary policy interest (see for instance Praet (2014)) in the well-functioning of the banking sector and the effects of the bank credit activity on the macroeconomy.

Central bank policy measures can affect loan supply (and consequently real economic activity and inflation) through several transmission channels ${ }^{1}$ : the credit channel (that encompasses the bank lending channel and the balance sheet channel), the bank capital channel, and the risk-taking channel. The bank lending channel theory states that banks respond to negative monetary policy shock (i.e. contraction) by reducing the supply of loans, which in turn negatively affects macroeconomic activity (Kakes \& Sturm, 2002). It recognizes banks as intermediaries well suited to solve asymmetric information problems present in the credit markets (Bernanke \& Blinder, 1988; Bernanke \& Gertler, 1995; Bernanke et al., 1999; Boivin et al., 2010). For the bank lending channel to be operational, three conditions must be met. First, there must be borrowers who are dependent on banks for their financing. Second, there must be information asymmetries in the loan market. These two conditions together imply that certain (retail) borrowers will not have access to credit markets unless they can borrow from banks. The third condition is that the loan supply of banks is affected by monetary policy measures (Bernanke \& Blinder, 1988; Kashyap \& Stein, 1994; Peek \& Rosengren, 2013). Under these conditions, a restrictive monetary policy will lead to a decrease in bank reserves and deposits. Consequently, banks will cut back the supply of loans which in turn weighs negatively on investment activity and economic growth. Monetary policy will have a greater macroeconomic impact, and thus the bank lending channel will be of greater relevance for the transmission of monetary policy impulses, if there is a greater share of small firms in the market and if the financial system is more bank-centered (Boivin et al., 2010).

\footnotetext{
1 For a comprehensive description of monetary policy transmission channels, see for instance Bernanke and Getler (1995), Gertler and Kiyotaki (2010), Boivin et al. (2010) or Peek and Rosengren (2013).
} 
The bank lending channel can be characterized as a bank balance sheet channel. Although bank funds do not consist exclusively of insured deposits, non-deposit sources of funding are likely to be relatively more expensive than deposits, reflecting the credit risks associated with uninsured lending (Stein, 1998). Moreover, the cost and availability of nondeposit funds for any given bank will depend on the perceived creditworthiness of the institution. Thus, the concerns of holders of uninsured bank liabilities about bank credit quality generate an external finance premium for banks that is similar to that faced by other (non-banking) borrowers (Bernanke, 2007).

Empirical evidence in support of the bank lending channel is mixed. Some earlier studies do not support the view that the bank lending channel is operational (including Romer and Romer (1990) or Ramey (1993)), while the newer studies provide support for the existence and importance of the channel (Gertler \& Gilchrist, 1993 1994; Kashyap \& Stein, 1994, 1995; Peek \& Rosengren, 1995; Lown \& Morgan, 2002; Hempell \& Sorensen, 2010; Ciccarelli et al., 2010; Cappiello et al., 2010).

If the bank lending channel is operational, then after a monetary policy tightening, a reduction in bank loan supply should be observed. Empirical investigation of the bank lending channel reveals an identification challenge: a decline in the volume of bank loans following a tightening of monetary policy (monetary policy shock) may simply reflect a decline in the demand for loans rather than a decline in the supply of loans (Peek \& Rosengren, 2013). A slack in credit activity in the euro area in the aftermath of the global financial crisis, observed in the aggregate statistical data, thus could be a reflection of worsened financial position of borrowers (bank and households), the capital and liquidity constraints of the lenders (banks), their increased risk aversion or a results of grimmer economic outlook that has induced a weaker demand for loans (Ciccarelli et al., 2010).

To disentangle the loan demand from loan supply response to a monetary policy shock, the existent literature can be separated into two general approaches. The first one relies on micro data; i.e. individual bank and borrower data (Gertler \& Gilchrist, 1993, 1994; Kashyap \& Stein, 1995; Gilchrist \& Zakrajsek, 1998), while the second focuses on macro data (Lown \& Morgan, 2002; Hempell \& Sorensen, 2010; Ciccarelli et al., 2010; Cappiello et al., 2010). As argued by Gertler and Gilchrist (1994) and Ciccarelli et al. (2010), the use of micro-identification presents the problem of separating the balance sheet channel (broad credit channel) and the bank lending channel as well as the problem of separating the supply from demand for loans, because it relies on actual loans granted that are a non-perfect proxy for an unobserved variable of loan demand. Due to these downsides of the micro data approach, this paper applies an identification approach that relies on macro data.

This paper aims to provide evidence on whether the bank landing channel in the selected euro area countries as a whole is operational and whether it works more through loans to large enterprises or loans to the SMEs. We identify the loan supply shocks attributable to the banks' balance sheet constraints and use them in a typical monetary policy

${ }^{2}$ Bank capital adequacy is another factor that affects bank lending capacity. However, bank capital constraints can be regarded as a factor that
VAR model (e.g. Christiano et al., 1996; Ciccarelli et al., 2010) to provide evidence of the existence of the bank lending channel and how the credit cycle affects the output and inflation in the euro area.

To identify the loan supply shocks attributable to the balance sheet constraints of banks we rely on the responses from the European Central Bank Bank Lending Survey (ECB BLS). A similar approach was applied by the studies of Hempell and Sorensen (2010), Ciccarelli et al. (2010), and Cappiello et al. (2010) for the euro area and Lown and Morgan (2002, 2006) and Bassett et al. (2012) for the U.S. These studies use the banks' responses on the factors affecting changes in credit standards and the dynamic panel (Hempell \& Sorensen, 2010; Cappiello, 2010) or panel vector autoregression (Ciccarelli et al., 2010) econometric methodology to separate the demand from the supply of loans shocks and to measure the loan supply reaction to monetary policy shock and the consequent macroeconomic effects. For the euro area, Ciccarelli et al. (2010) find that for business loans, the macroeconomic impact of the monetary policy through the (supply) bank lending channel is higher than through other channels of monetary policy (the demand and balance-sheet channels). Hempell and Sorensen (2010) conclude that the bank lending channel is operational in the euro area as the loan growth is negatively affected by supply-side constraints even when controlling for the effects coming from the demand side. Also the results of the study of Cappiello et al. (2010) show that the bank lending channel in euro area is operational and that the supply of credit have significant effects on real economic activity.

To our best knowledge, none of the existent studies that rely on bank lending survey responses investigates whether the functioning of the bank lending channel is more operational for the large enterprises than for the SMEs. This paper aims to fill this gap.

\section{Methodology}

This paper joins the recent practice in the empirical literature that disentangles the demand from supply loan shocks and different channels of monetary policy transmission by applying the central bank's bank lending surveys (Lown \& Morgan, 2002; Lown \& Morgan, 2006; Hempell \& Sorensen, 2010; Ciccarelli et al., 2010; Cappiello et al., 2010; Bassett et al., 2012). As we already noted, the bank lending channel is the bank balance sheet channel. The ECB BLS covers bank responses to the banks' balance sheet constraints factors that affect credit standards aggregated for enterprises of all sizes and separately for the large enterprises and the SMEs, respectively: bank liquidity constraints (the survey names this factor as "impact of bank liquidity position"), constraints in the access to market funding ("impact of ability to access market financing"), constraints induced by non-bank competition ("impact of non-bank competition"), and constraints induced by other banks ("impact of bank competition") ${ }^{2}$. The four ECB BLS

determines the functioning of the bank capital channel (see Borio and Zhu (2008) and Dell Ariccia et al. (2011)). 
responses are used to form a composite variable ${ }^{3}$ of credit standards changes for the large enterprises and the SMEs respectively, that are attributed to the balance sheet constraints of banks. This composite variable is then used in the panel VAR model, and consequently, the impulse response functions are calculated. An innovation (i.e. impulse response) of business loans volume to a shock in the composite variable of balance sheet constraints of banks is interpreted as a (aggregate) business loan supply response to the banks' balance sheet constraints shock. As we do not have the access to data for business loans volume for the large enterprises and the SMEs separately for all the euro area countries on a quarterly frequency, we hesitate to interpret the impulse responses of the composite variables for the large enterprises and the SMEs, respectively, as the effects of the banks' balance sheet constraints shocks on the credit supply for the large enterprises and the SMEs, respectively.

To gain the knowledge of whether the bank lending channel is operational we investigate the impulse response function of the banks' credit standards for enterprises related to factors affecting banks' balance sheet constraints (i.e. in the composite variable of the banks' balance sheet constraints) to a monetary policy shock. The significance and the size of the impact of a one standard deviation shock in the monetary policy rate on the credit standards for large enterprises, and the SMEs respectively, attributed to the banks' balance sheet constraints is analyzed to infer about the importance of the bank lending channel for the loans to large enterprises and the SMEs respectively.

We estimate two panel vector autoregression (VAR) models with fixed effects. The first one (1) is utilized to analyze whether the bank lending channel is operational through the changes in the credit standards for large enterprises attributed to the banks' balance sheet constraints. The reduced-form of the VAR model can be written as:

$$
\begin{aligned}
& Y_{i t}=A(L)\left(G D P_{i t}+H_{I C P_{i t}}+E_{\text {EONIA }}+B L O A N S_{i t}+\right. \\
& \left.+C B B S C_{-} L C_{i t}\right)+\eta_{i}+\varepsilon_{i t}, \quad i=1, \ldots, N ; t=1, \ldots, T
\end{aligned}
$$

where $i$ refers to a particular country, $t$ to time and the endogenous variables are the ones that are usually applied in the standard monetary VARs (e.g. Christiano et al., 1996; Ciccarelli et al., 2010), including a real GDP (log) growth rate, the $(\log )$ growth rate of Harmonized Consumer Price Index (HICP), and a monetary policy rate (EONIA is used as in several recent studies for euro area ${ }^{4}$ ). Following Lown and Morgan (2006) we include two additional endogenous variables: a growth rate of volume of loans to enterprises (BLOANS) and the (composite variable of) changes in credit standards for large enterprises attributable to the

\footnotetext{
${ }^{3}$ A reduction in the number of variables is performed in order to reduce the number of variables in the panel VAR model. A similar exercise is performed for instance by Ciccarelli et al. (2010), yet with another method (simple average of credit standards diffusion indexes). The composite variable obtained by principal component analysis contains the majority of the variability of the original variables.

${ }^{4}$ See Ciccarelli et al. (2010) and Busch et al. (2010).

${ }^{5}$ Vanessa Love's (Love and Zicchino, 2006) code was used to estimate the panel VAR models.

${ }^{6}$ Recursive (Cholesky) structure of the contemporaneous relationships of the variables is the prevailing practice of solving the identification issue in monetary VARs. However, when indentifying assumptions are changed the resulting impulse response functions may change. As all of the reviewed
}

balance sheet constrains of banks (CBBSC_LC). $A(L)$ is a matrix polynomial in the lag operator for the vector of endogenous variables, $\eta_{i}$ is a vector of country-specific (unobservable) fixed-effects, and $\varepsilon_{i t}$ is a vector of idiosyncratic errors.

The second panel VAR model (2) is utilized to analyze whether the bank lending channel is operational through the changes in credit standards for the SMEs attributed to the banks' balance sheet constraints. In reduced-form the second panel VAR model can be written as:

$$
\begin{aligned}
& Y_{i t}=A(L)\left(G D P_{i t}+H_{I C P}+P_{i t} \text { EONIA }_{t}+B L O A N S_{i t}+\right. \\
& \left.+C B B S C \_S M E_{i t}\right)+\eta_{i}+\varepsilon_{i t}, i=1, \ldots, N ; t=1, \ldots, T(2)
\end{aligned}
$$

where CBBSC_SME is the composite variable of changes in the credit standards for the SMEs attributable to the balance sheet constrains of banks. The lag order of models (1) and (2) are selected based on minimization of the Andrews and Lu (2001) model and moment condition selection (MMSC) method based on Akaike's information criteria 5 .

To identify the VAR models, we used the Choleski decomposition of the variance-covariance matrix of residuals of the reduced-form VAR model. Because the ordering of variables is important in this case, it is based on the empirical literature (e.g. Bernanke \& Mihov, 1995; Christiano et al., 1996; Leeper et al., 1996; Bagliano \& Favero, 1998; Lown \& Morgan, 2006), placing GDP growth rate as the first variable, price index growth rate as the second, monetary policy rate as the third and the credit market variables as the last (business loans volume preceding changes in the credit standards $)^{6}$.

As proved by Nickell (1981), the fixed-effects estimator of the models (1) and (2) is not consistent because the country-specific fixed effects are very likely correlated with the lagged endogenous variable in the models. One of the approaches to correct for the inconsistency of the estimator is to estimate models (1) and (2) with the procedure prescribed by Holtz et al. $(1988)^{7}$. Following this procedure the data is Helmert transformed prior the VAR model is estimated. For that purpose, let us write all the endogenous variables of model (1) (and (2) respectively) in the vector of endogenous variables $Y_{i t}$ :

$$
Y_{i t}=A(L) Y_{i t}+\eta_{i}+\varepsilon_{i t}, \quad i=1, \ldots, N ; t=1, \ldots, T,(3)
$$

The Helmert method (that removes the fixed effects from the models (1) and (2) respectively) consists of forward mean-differencing the original data (Arellano \& Bover 1995; Boubtane et al., 2012):

$$
\tilde{y}_{i t}^{m}=\delta_{i t}\left(y_{i t}^{m}-\bar{y}_{i t}^{m}\right)
$$

papers that use Choleski decomposition order GDP growth first, followed by inflation and then monetary policy rate, we, as a part of the robustness test of the results, tested only whether changing the order of the volume of the loans and credit standards in the VAR models (1) and (2) affects impulse responses. We found the results and implication not to be affected. Alternatively, one could use for instance the generalized impulse responses (Pesaran and Shin, 1998), yet none of the monetary policy transmission mechanism studies referenced in this paper applied this approach.

${ }^{7}$ This procedure has been extensively applied by several authors in the empirical panel VAR modelling, including among others Love and Zicchino (2006), Boubtane et al. (2012), and de Haan and van den Ende (2011). 
and

$$
\tilde{\varepsilon}_{i t}^{m}=\delta_{i t}\left(\varepsilon_{i t}^{m}-\bar{\varepsilon}_{i t}^{m}\right),
$$

where $m=1, \ldots, M$ is the number of endogenous variables in model (1) (and model (2) respectively), $\bar{y}_{i t}^{m}=$ $\sum_{s=t+1}^{T_{i}} y_{i s}^{m} /\left(T_{i}-t\right)$ are the means obtained from the future values of a variable $y_{i s}^{m}$ in the vector $Y_{i t}=\left(y_{i t}^{1}, y_{i t}^{2}, \ldots, y_{i t}^{M}\right)^{\prime}$, and $\bar{\varepsilon}_{i t}^{m}$ from the future values of $\varepsilon_{i t}^{m}$, where $\varepsilon_{i t}=$ $\left(\varepsilon_{i t}^{1}, \varepsilon_{i t}^{2}, \ldots, \varepsilon_{i t}^{M}\right)^{\prime} ; T_{i}$ is the last available observation (i.e. period) in the sample, $\delta_{i t}=\sqrt{\frac{T_{i}-t}{T_{i}-t+1}}$ is a weighting factor included to equalize the variances. With Helmert transformation the last time observation for each panel (country) is lost from the sample.

Using Helmert transformed variables, model (3) can be rewritten as:

$$
\tilde{Y}_{i t}=A(L) \tilde{Y}_{i t}+\tilde{\varepsilon}_{i t},
$$

Consistent parameter estimates of model (1) and (2) are thus obtained by retransforming to and estimating model (6) using the generalized method of moments (GMM) with the non-transformed variables used as instrumental variables (Arellano \& Bover, 1995; Love \& Zicchino, 2006).

The prime interest of this research, however, is not only to estimate parameters of VAR models (1) and (2) but also to calculate and draw the resulting impulse response functions to analyze the macroeconomic effects of shocks in credit standards for business loans attributed to the banks' balance sheet constrains and to evaluate whether the bank lending channel is operational in the selected euro area countries as a whole.

As suggested by Love and Zicchino (2006), confidence intervals for the impulse response functions are not constructed analytically but rather Monte Carlo simulation is used to generate a 95-percent confidence interval.

\section{Data}

The dataset consists of quarterly data for the period 2008:Q1-2014:Q3 for ten euro area countries: Austria, France Germany, Ireland, Italy, Luxembourg, Netherlands, Portugal, Slovenia, and Spain. Other euro area countries are not included either because the key data - i.e. data on diffusion indexes on credit standards (see continuation of the section for description of the data), was publicly unavailable at the time of writing (Finland, Greece, Belgium) or available only for the later periods (Cyprus, Estonia, Malta, Latvia, Lithuania, and Slovakia). The period of observation is limited with the availability of data. Data for the factors affecting changes in credit standards for large and SMEs respectively are available from the first quarter of 2008 forward only. Data definitions and sources are presented in Table 1.

For the model (6) to yield consistent estimates, the variables have to be stationary.

\section{Variables used and their description}

Table 1

\begin{tabular}{|l|l|c|}
\hline \multicolumn{1}{|c|}{ Variable } & \multicolumn{1}{|c|}{ Description } & Source \\
\hline Credit standards for loans to enterprises & Diffusion index of credit standards for loans to enterprises & ECB \\
\hline Volume of loans to enterprises & Loans to non-financial corporations (outstanding), quarter-on-quarter (log) growth & ECB \\
\hline GDP & $\begin{array}{l}\text { Real GDP (seasonally adjusted and working days adjusted), quarter-on-quarter } \\
\text { (log) growth }\end{array}$ & Eurostat \\
\hline Price index (HICP) & Harmonized Consumer Price Index, quarter on quarter (log) growth & Eurostat \\
\hline EONIA & Euro Overnight Index Average, quarter average & ECB \\
\hline $\begin{array}{l}\text { Credit standards factor of bank liquidity } \\
\text { constraint }\end{array}$ & $\begin{array}{l}\text { Diffusion index for the loans to enterprises credit standards factor "Impact of } \\
\text { liquidity position" }\end{array}$ & ECB \\
\hline $\begin{array}{l}\text { Credit standards factor of balance sheet } \\
\text { constraint induced by access to market funding }\end{array}$ & $\begin{array}{l}\text { Diffusion index for the loans to enterprises credit standards factor "Impact of } \\
\text { ability to access market financing" }\end{array}$ & ECB \\
\hline $\begin{array}{l}\text { Credit standards factor of constraint induced by } \\
\text { non-bank competition }\end{array}$ & $\begin{array}{l}\text { Diffusion index for the loans to enterprises credit standards factor "Impact of non- } \\
\text { bank competition" }\end{array}$ & ECB \\
\hline $\begin{array}{l}\text { Credit standards factor of balance sheet } \\
\text { constraint induced by other banks }\end{array}$ & $\begin{array}{l}\text { Diffusion index for the loans to enterprises credit standards factor "Impact of bank } \\
\text { competition" }\end{array}$ & ECB \\
\hline
\end{tabular}

Notes: ${ }^{\mathrm{A}}$ These four ECB BLS data were used to construct a composite variable of changes in credit standards for large (and SME respectively) that are attributed to the balance sheet constraints of banks.

The Im-Pesaran-Shin (IPS) unit root test (Im et al., 2003) was applied to verify that the panel data are stationarity ${ }^{1}$. GDP, price index, EONIA, and volume of loans to enterprises are expressed as logarithmic (log) growth rates on a quarter-to-quarter basis rather than on a 4quarter basis as the stationarity tests indicated that expressing the data as 4-quarter growth rates does not remove the unit root. Results are presented in Table 2.

\footnotetext{
${ }^{1}$ The monetary policy rate variable (EONIA) is common to all countries as they all share the same monetary union monetary policy. Therefore the stationarity was tested by the KPPS (Kwiatkowski-Phillips-Schmidt-
}

Shin) test. The null of stationarity was not rejected at $1 \%$ level significance level. 
Results of the panel unit root test for variables in the VAR model (2)

\begin{tabular}{|l|c|c|}
\hline \multicolumn{1}{|c|}{ Variable in the model (4) } & IPS test & IPS test (demeaned series) \\
\hline $\begin{array}{l}\text { Diffusion index of credit standards for loans to } \\
\text { large enterprises }\end{array}$ & $-2.4427(0.0073)$ & $-5.5501(0.0000)$ \\
\hline $\begin{array}{l}\text { Diffusion index of credit standards for loans to } \\
\text { SME }\end{array}$ & $-3.3628(0.0004)$ & $-6.2765(0.0000)$ \\
\hline $\begin{array}{l}\text { Diffusion index of the composite variable of } \\
\text { credit standards for large enterprises }\end{array}$ & $-4.3525(0.0000)$ & $-2.1871(0.0144)$ \\
\hline $\begin{array}{l}\text { Diffusion index of the composite variable of } \\
\text { credit standards for SME }\end{array}$ & $-5.9710(0.0000)$ & $-4.9501(0.0000)$ \\
\hline $\begin{array}{l}\text { Volume of loans to enterprises, quarter-on- } \\
\text { quarter growth }\end{array}$ & $-4.5726(0.0000)$ & $-5.6397(0.0000)$ \\
\hline GDP, quarter-on-quarter growth & $-7.7301(0.000)$ & $-10.9340(0.0000)$ \\
\hline Price index (HICP), quarter-on-quarter growth & $-3.0141(0.0013)$ & $-4.7098(0.0000)$ \\
\hline
\end{tabular}

Notes: The null of the IPS test is that all panels $(i ; i=1, \ldots, N)$ contain a unit root, while the alternative is that the fraction of panels that follow stationary processes is nonzero. Serially correlated errors are allowed for in the test, and the Akaike information criteria (AIC) is used to choose the appropriate lag length. The test statistic (denoted $W_{t-b a r}$ in the original paper of Im et al. (2003)) and the corresponding p-values are reported. The IPS test (demeaned series) reports the test statistic and the corresponding p-values of the IPS test on the demeaned panel series. Namely, Levin et al. (2002) suggested that the data should be demeaned prior to applying the IPS test in order to mitigate the impact of cross-sectional dependence.

Source. Own calculations.

Three variables that are nonstationary in levels were tested for cointegration. The test of Westerlund (2007) indicates (Table 3 ) that there is no cointegration between the variables. The panel VAR model (4) that yields consistent estimates can therefore be applied.

Table 3

Results of the Westerlund's cointegration tests

\begin{tabular}{|c|c|c|}
\hline Test statistic & Value of the test statistic & Robust p-value \\
\hline$G_{\tau}$ & -0.908 & 0.969 \\
\hline$G_{\alpha}$ & -1.024 & 0.999 \\
\hline$P_{\tau}$ & -0.958 & 0.954 \\
\hline$P_{\alpha}$ & -0.680 & 0.951 \\
\hline
\end{tabular}

Notes: Persyn and Westerlund' s (2008) codes were used for the test. The null hypothesis is no cointegration between variables. For the details of the test see Westerlund (2007). The statistic was bootstrapped (with 1000 replications) and the yielding robust p-value is reported. We allow for the constant and let the AIC determine the optimal number on lags in the error-correction model. $G_{\tau}$ and $G_{\alpha}$ are group mean statistics that test whether cointegration exists for at least one cross-sectional unit (country), where $\tau$ denotes that the standard errors are computed in a standard way, while $\alpha$ denotes that standard errors, adjusted for heteroscedasticity and autocorrelation, are computed by Newey and West (1994) procedure. $P_{\tau}$ and $P_{\alpha}$ are total panel mean statistics that pool information over all cross-section units and test for cointegration in the panel as a whole. In simulation study Westerlund (2007) proved that $G_{\tau}$ and $P_{\tau}$ perform better than the two other tests.

Source: Own calculations.

\section{Results}

Figure 1 plots the diffusion indexes for the credit standards that the banks reported to had applied to the loans for the large enterprises and the SMEs. The euro area banks reported tightened standards (as compared to the previous reporting quarter) for the large enterprises and the SMEs from the start of the observed period to the third quarter of 2013. The pace of tightening was moderated during the period from 2008 to the end of 2010. In 2011, probably due to a slowdown in economic activity in the euro area, the tightening of credit standards increased again. In 2013, a "pronounced (weighted) net decline in tightening ${ }^{9}$ can be observed, and in 2014, the easing of credit standards occurred. Over the whole observed period, credit standards had been generally tightened more for the large enterprises than for the SMEs ${ }^{10}$, with the exception of the second quarter of 2010 and the first three quarters in 2013.

\footnotetext{
${ }^{9} \mathrm{ECB}$ (2015) refers to the decline in (weighted) net tightening between two (or more) ECB BLS waves as a "more pronounced net decline in credit standards tightening".

${ }^{10}$ The ECB BLS reports changes in (weighted) net tightening. It does not report on the level of tightening. One must therefore be careful not to interpret a higher average net tightening as a higher credit standards level
}

The (principal component) composite indicators of changes in the credit standards for the large enterprises and the SMEs attributed to the banks' balance sheet constraints are drawn in Figure 2. Banks' balance sheet constraints weighed negatively on credit standards set especially in the period from the first quarter of 2008 until the end of the first quarter of 2009 and to a lesser extent in 2011. In other periods the banks' balance sheet constraints did not contribute to tightening of credit standards. Apparently, other factors contributed to the tightening observed in the period 2008:Q1-2013:Q3 (Figure 1), such as demand factors (expectations regarding economic outlook and industry outlook) and maybe also other supply-related factors (bank capital constraints and risk-aversion of banks) ${ }^{11}$.

for the large enterprises as compared to that which SMEs have to satisfy to obtain a loan from the bank.

${ }^{11}$ A research on how these other factors affect dynamics of credit standards of loans to enterprises is out of the scope of this research and left for a future research. 


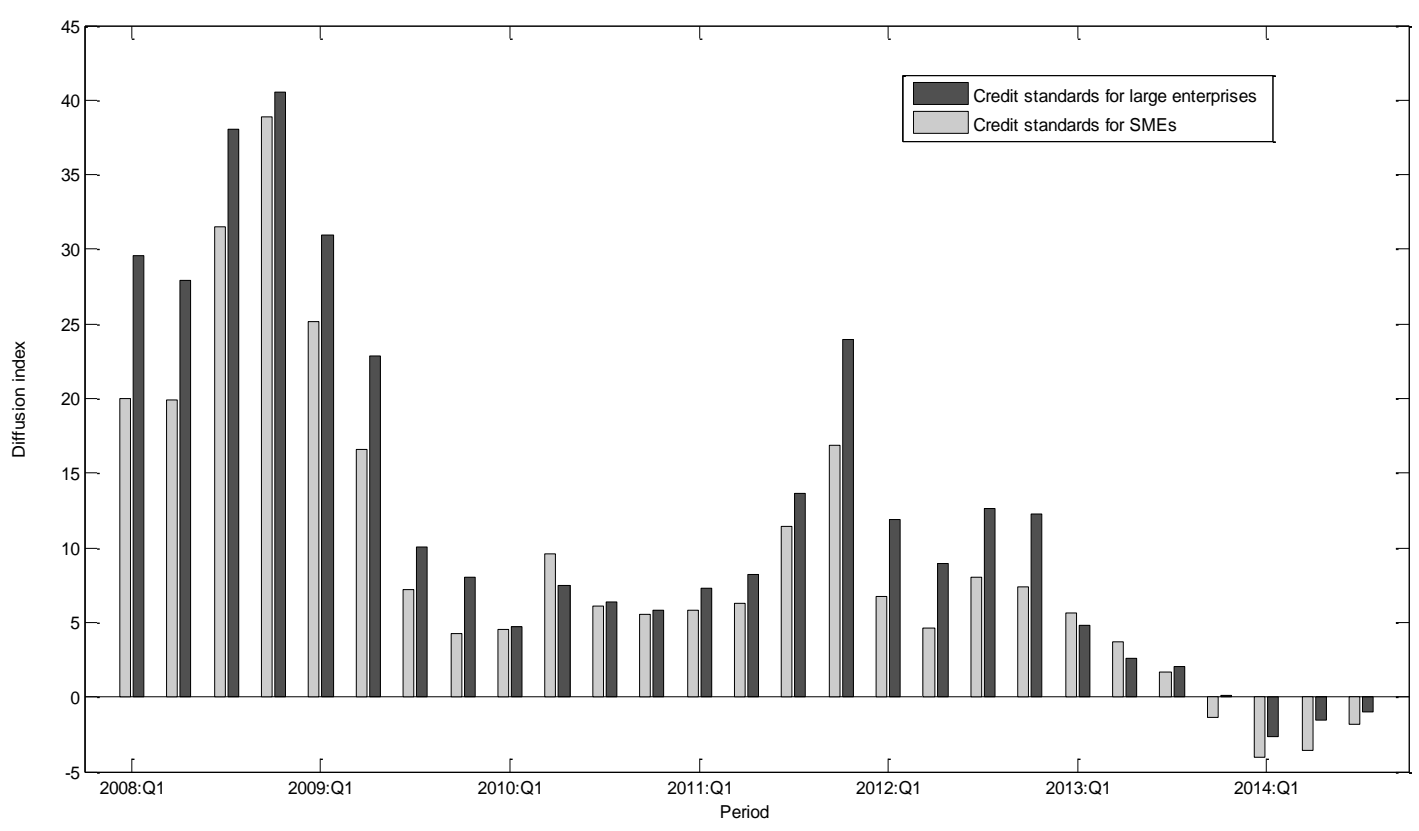

Figure 1. Changes in credit standards for the large enterprises and the SMEs during period 2008:Q1-2014:Q3

Notes: The figure shows the average diffusion index of credit standards for the large enterprises and the SMEs of the observed countries. Source of data: $E C B$ BLS.

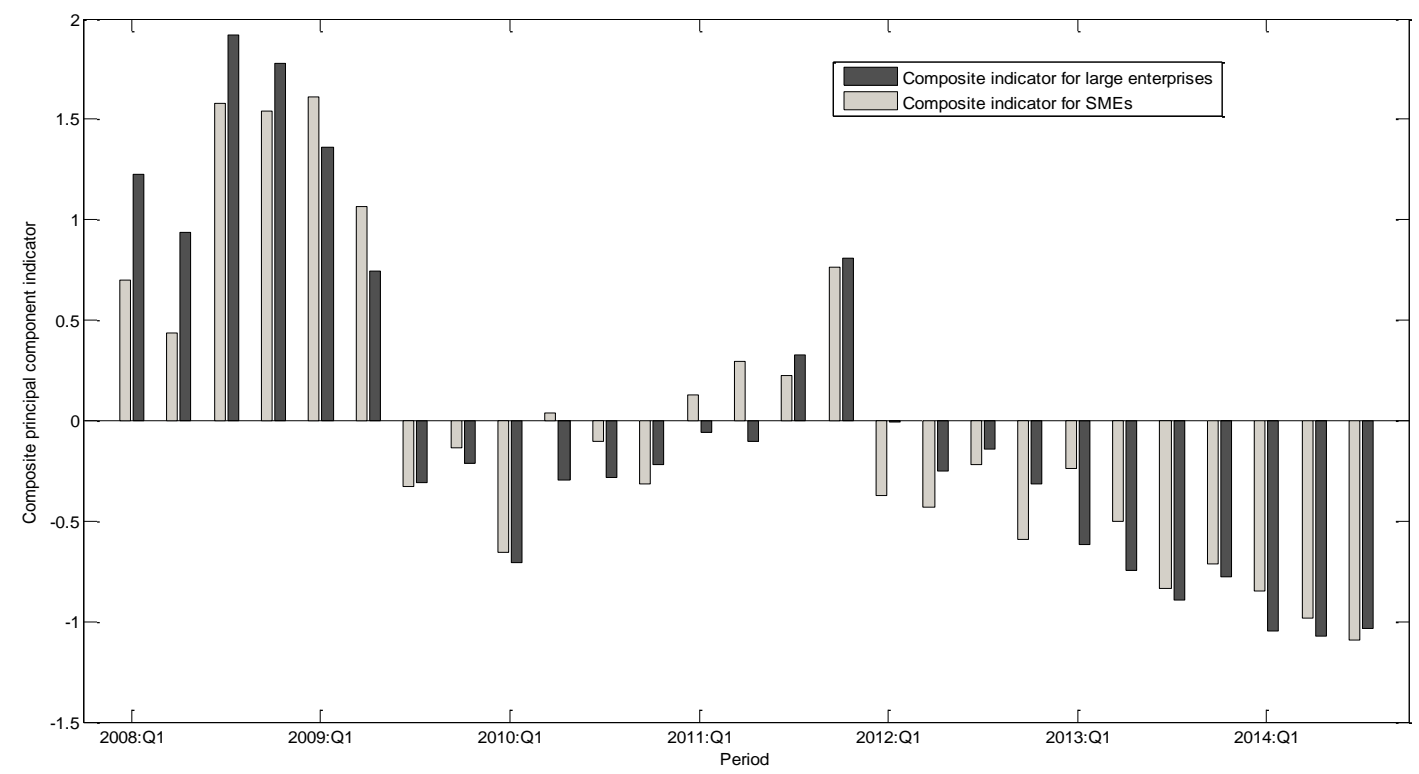

Figure 2. Changes in credit standards for the large enterprises and the SMEs attributed to the banks' balance sheet constraints

Notes: One principal component indicator of changes in credit standards attributed to the banks' balance sheet constraints (separately of the large and the SMEs) was formed from the diffusion indexes of credit standards factors: "impact of liquidity position", "impact of ability to access market financing", "impact of non-bank competition", and "impact of bank competition". Average values of indicators for the euro area countries included in the sample are presented.

Source: Own calculations.

The impulse response functions (IRFs) of the VAR model (1), i.e. the model that is used to test to what extent the bank lending channel is operational for the loans to large enterprises, are plotted in Figure 3. In the graph a, the IRF of credit standards to a one standard deviation shock in monetary policy rate (EONIA) is drawn. A negative shock (an increase in the policy rate) leads to a significant increase in credit standards for large enterprises. The effect is the 
strongest a quarter after the shock, and then it gradually fades away. This may suggest that the restrictive monetary policy shock increases the banks' balance sheet constraints and banks in the short run respond by tightening credit standards for large enterprises.

The graph $b$ reveals that a shock of tightening credit standards (attributed to the banks' balance sheet constraints) leads to a short-run drop in the GDP growth rate. The graph c shows that the monetary policy responds to a negative credit standards shock by a more accommodative monetary policy stance (a drop in EONIA rate). Tightening credit standards shock affects negatively the growth of business loans (the graph e): two quarters after a one standard deviation shock a drop of credit activity of approximately 0.3 percent can be observed. A credit standards shock (attributed to banks' balance sheet constraints) does not significantly affect inflation rate (graph d).

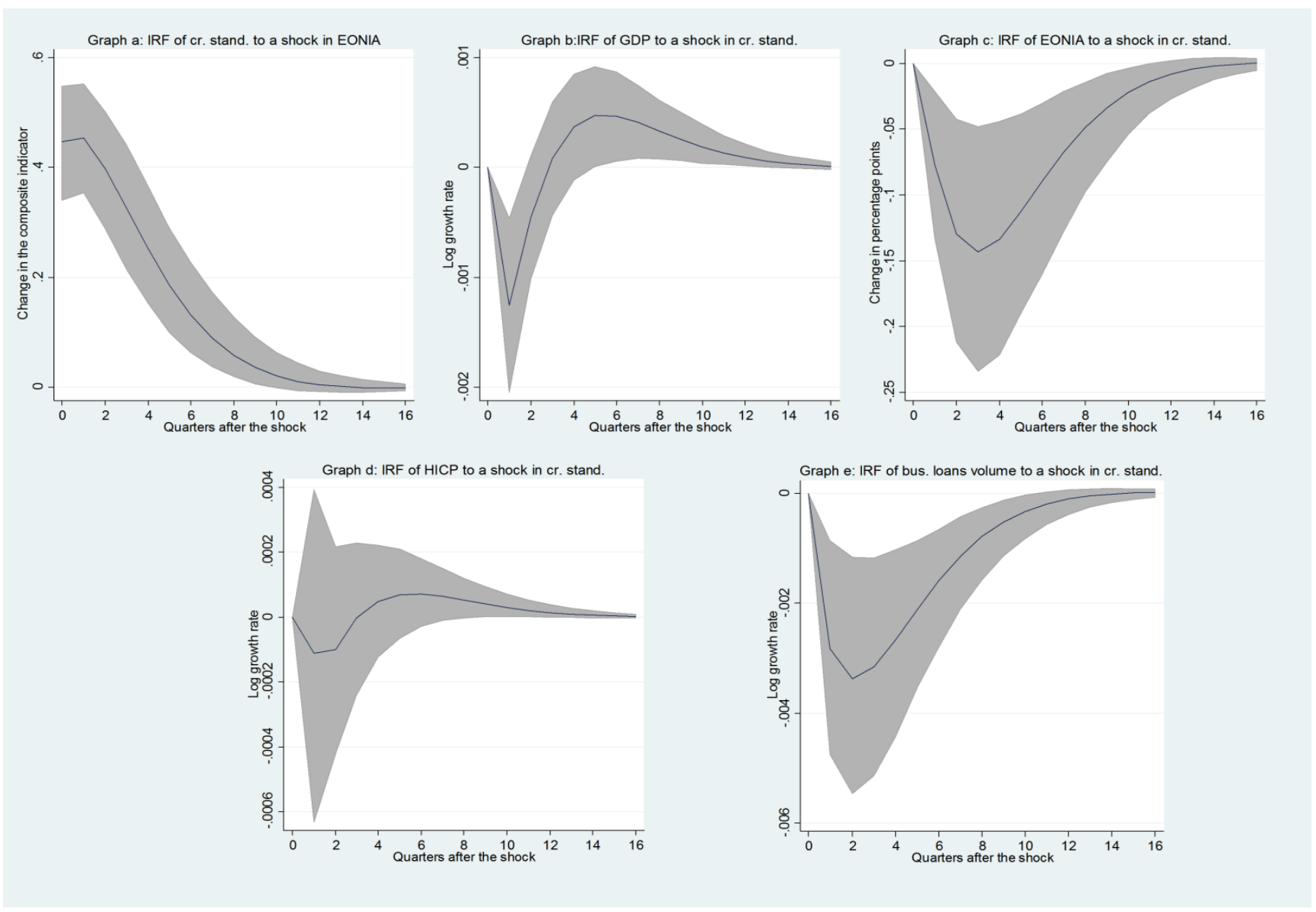

Figure 3. Impulse response functions of VAR model (1) variables (i.e. the model for the large enterprises) to a shock in monetary policy rate (EONIA) and a shock in credit standards attributed to banks' balance sheet constraints

Notes: the impulse response functions (IRFs) to a one standard deviation shock in monetary policy rate (EONIA) and credit standards for large enterprises attributable to banks' balance sheet constraints are drawn. Log growth rate is a change in logarithm of the variable. A low growth of -0.01 corresponds to a 1 percent drop in the variable. A one standard deviation of the composite variable of credit standards changes for large enterprises attributable to the banks' balance sheet constraints for the whole observed period is 1.524 . Thus, a one standard deviation shock in EONIA leads after 1 quarter to approximately a 0.3 standard deviation increase in credit standards for large enterprises attributed to (increased) banks'balance sheet constraints.

Source: Own calculations.

Figure 4 plots the IRFs of variables to a one standard deviation shock in a monetary policy rate (EONIA) and in credit standards for SMEs attributed to balance sheet constraints of banks (model (2)). A negative monetary policy shock leads to a relatively smaller increase in credit standards for loans to SMEs (a 0.24 standard deviation, see notes to Figure 4) than for large enterprises, and the effect is no more the greatest after one but two quarter after the shock (graph a). The effect of credit standards shock for the SMEs on real GDP is practically identical in magnitude and dynamics as that for the large enterprises (graph b). The monetary policy seems to respond in a more pronounced manner to a credit standards shock for loans to SME than to large enterprises (graph c). The effect of the credit standards shock for loans to SMEs on the volume of (overall) business loans is relatively more moderate than in the case of a shock in credit standards for large enterprises (graph e). The result is expected, as the large enterprises can more easily access other non-bank external sources of funding than SMEs can. When credit standards for SMEs are tightened because banks' balance sheet constraints have increased, the volume of (overall) loans to enterprises is hardly affected in the medium term. A credit standards shock (attributed to banks' balance sheet constraints) for loans to SMEs does not significantly affect inflation rate (graph d). 


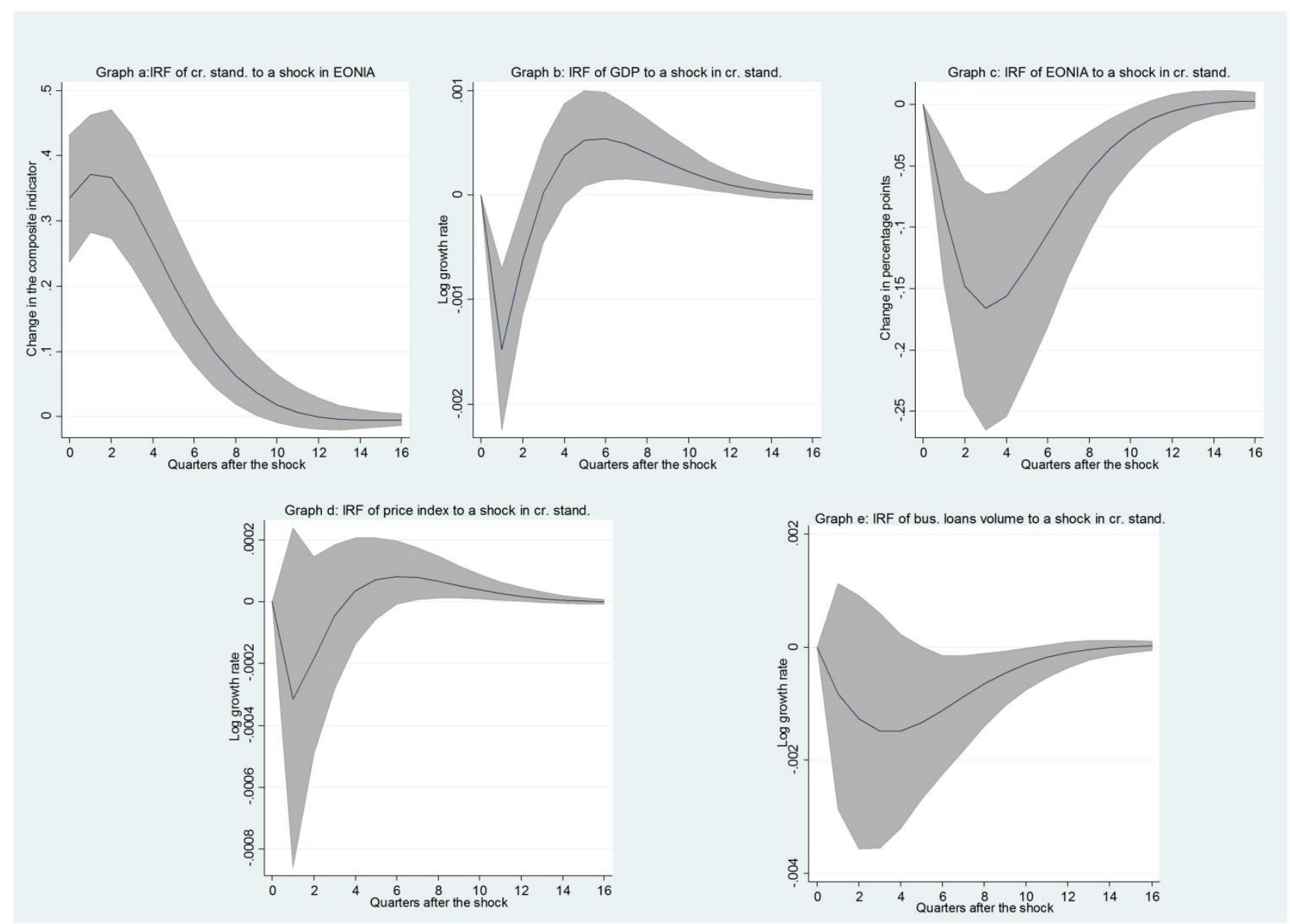

Figure 4. Impulse response functions of VAR model (2) variables (i.e. the model for the SMEs) to a shock in monetary policy rate (EONIA) and a shock in credit standards for loans attributed to banks' balance sheet constraints

Notes: Impulse response functions (IRFs) to a one standard deviation shock in monetary policy rate (EONIA) and credit standards for large enterprises attributable to banks' balance sheet constraints are drawn. A one standard deviation of the composite variable of credit standards changes for SMEs attributable to the banks' balance sheet constraints for the whole observed period is 1.47. Thus, a one standard deviation shock in EONIA leads after 2 quarters to approximately 0.24 standard deviation increase in credit standards for SME attributed to (increased) banks' balance sheet constraints. Source: Own calculations.

Significant impulse response functions of credit standards for loans to large enterprises and to SMEs lead us to conclude that a restrictive monetary policy impulse increases the balance sheet constraints that the euro area banks face. Statistical data indicate that especially liquidity position ${ }^{1}$ of banks is affected. In turn, increased balance sheet constraints lead banks to tighten credit standards and reduce loan activity. This evidence implies that the bank lending channel in the selected euro area countries as a whole is operational. The findings suggest also that it is more operational for the large enterprises than SMEs. One possible explanation for why banks tighten more credit standards for loans to large enterprises is that an average loan to a large enterprise in probably larger (and possibly longer term) than an average loan to SMEs and entails great risks.

\section{Conclusions}

This paper investigated whether the bank lending channel is operational in the selected euro area countries as

\footnotetext{
1 Among the four factors from which the composite variable of bank balance sheet constraints is formed, the liquidity position and access to
}

a whole and whether it works more through the loans to large enterprises or loans to SMEs. We identified shocks in credit standards applied to business loans by relying on the responses from the ECB BLS and applied the panel vector autoregression econometric methodology. The resulting impulse response functions were used to measure macroeconomic effects of shocks in the monetary policy interest rate and the banks' credit standards.

The ECB BLS shows that the euro area banks reported to had tightened standards (as compared to the previous reporting quarter) for large enterprises and SMEs each consecutive quarter from the start of the observed period to the third quarter of 2013. The pace of tightening was moderated during the period from 2008 to the end of 2010 . In 2011, probably due to a slowdown in economic activity in the euro area, the strength of tightening credit standards increased again. In 2013, a pronounced (weighted) net decline in tightening can be observed and in 2014, the easing of credit standards occurred. Over the whole observed period, credit standards had been generally tightened more for

wholesale funding markets exert the highest volatility in the observed period. 
large enterprises than for SMEs, with the exception of the second quarter of 2010 and the first three quarters in 2013. We found that the banks' balance sheet constraints weighed negatively on credit standards especially in the period from the first quarter of 2008 until the end of the first quarter of 2009 and to a lesser extent in 2011.

We found that tightening in monetary policy negatively impacted banks' balance sheet constraints and led banks to tighten credit standards more for large enterprises than for SMEs. Tightened credit standards for loans in turn resulted in a drop in outstanding loans. The results of the study imply that the bank lending channel is operational. The findings suggest also that it is more operational for the large enterprises than SMEs - in response to a negative monetary policy shock banks tighten credit standards more for the large as for the SMEs.

Another finding of the research is that after a negative shock to the credit standards, output is likely to be reduced in the short run yet no significant impact on inflation can be expected.

The impulse response analysis results also show that in the observed period the European central bank responded to banks' tightening of credit standards. The central bank responded more after the banks tightened credit standards for the SMEs than for the large enterprises.

\section{References}

Andrews, D. W. K., \& Lu, B. (2001). Consistent model and moment selection procedures for GMM estimation with application to dynamic panel data models. Journal of Econometrics, 101(1), 123-164. http://dx.doi.org/10.1016/S03044076(00)00077-4

Arellano, M., \& Bover, O. (1995). Another look at the instrumental variable estimation of error component models. Journal of Econometrics, 68(1), 29-51. http://dx.doi.org/10.1016/0304-4076(94)01642-D

Bagliano, C. F., \& Favero, C. A. (1998). Measuring monetary policy with VAR models: an evaluation. European Economic Review, 42(6), 1069-1112. http://dx.doi.org/10.1016/S0014-2921(98)00005-1

Bassett, F. W., Chosak, M. B., Driscoll, J. C., \& Zakrajsek, E. (2012). Changes in bank lending standards and the macroeconomy. Federal Reserve Board Finance and Economics Discussion Series paper No. 2012-24.

Bernanke, B. S. (2007). The Financial Accelerator and the Credit Channel. The Credit Channel of Monetary Policy in the Twenty-first Century Conference, Federal Reserve Bank of Atlanta, Atlanta, Georgia, June 15, 2007.

Bernanke, B. S., \& Blinder, A. S. (1988). Is it Money or Credit, or both, or neither?. American Economic Review, 78(2), 435-439.

Bernanke, B. S., \& Gertler, M. (1995). Inside the Black Box: The Credit Channel of Monetary Policy Transmission. Journal of Economic Perspectives, 9(4), 27-48. http://dx.doi.org/10.1257/jep.9.4.27

Bernanke, B. S., Gertler, M., \& Gilchrist, S. (1999). The financial accelerator in a quantitative business cycle framework. In J. Taylor, and M. Woodford (Eds). Handbook on Macroeconomics (pp.1341-1393), Amsterdam: North-Holland.

Bernanke, B. S., \& Mihov, I. (1995). Measuring monetary policy. NBER working paper no. 5764.

Boivin, J., Kley, M. T., \& Mishkin, F. S. (2010). How has the monetary transmission mechanism evolved over time?, NBER working paper No. 15879.

Borio, C., \& Zhu, H. (2008). Capital regulation, risk-taking and monetary policy: a missing link in the transmission mechanism?. Bank for international settlements working papers No. 268.

Boubtane, E., Coulibaly, D., \& Rault, C. (2012). Immigration, Growth and unemployment: Panel VAR Evidence from OECD Countries. IZA Discussion Paper No. 6966.

Busch, U., Scharnagl, M., \& Scheithauer, J. (2010). Loan Supply in Germany During the Financial Crisis. Deutsche Bundesbank Discussion Paper Series No. 05/2010.

Cappiello, L., Kadareja, A., Sorensen, C. K., \& Protopapa, M. (2010). Do bank loans and credit standards have an effect on output?. ECB working paper series No. 1150.

Christiano, L. J., Eichenbaum, M., \& Evans, C. L. (1996). The effects of monetary policy shocks: Evidence from the flow of funds. Review of Economics and Statistics, 78(1), 16-34. http://dx.doi.org/10.2307/2109845

Ciccarelli, M., Maddaloni, A., \& Peydro, J. L. (2010). Trusting the bankers. A new look at the credit channel of monetary policy. ECB working paper series No. 1228.

De Haan L., \& van den Ende, J. W. (2011). Banks' responses to funding liquidity shocks: lending adjustment, liquidity hoarding and fire sales. DNB Working paper No. 293.

Dell Ariccia, G. D., Laeven, L., \& Marquez, R. (2011). Monetary policy, leverage and bank risk-taking. CEPR Discussion Paper No. 8199.

ECB. (2014). Survey on the access to finance of enterprises in euro area april 2014 - september 2014. Frankfurt.

ECB. (2015). The euro area bank lending survey, $4^{\text {th }}$ quarter of 2014 . Frankfurt.

Gertler, M., \& Gilchrist, S. (1993). The Role of Credit Market Imperfections in the Monetary Transmission Mechanism: Arguments and Evidence. Scandinavian Journal of Economics, 95(1), 43-64. http://dx.doi.org/10.2307/3440134 
Gertler, M., \& Gilchrist, S. (1994). Monetary Policy, Business Cycles, and the Behavior of Small Manufacturing Firms. The Quarterly Journal of Economics, 109(2), 309-40. http://dx.doi.org/10.2307/2118465

Gilchrist, M., \& Zakrajsek, E. (1998). The importance of credit for macroeconomic activity: identification through heterogeneity. In S. Brakman, H. van Ees, and S.K. Kuipers (Eds.). Market behaviour and macroeconomic modelling (pp. 221-241), London: MacMillan. http://dx.doi.org/10.1007/978-1-349-26732-3_5

Hempell, H. S., \& Sorensen, K. (2010). The impact of supply constraints on bank lending in the euro area - crisis induced crunching?. ECB working paper series No. 1262.

Holtz, E., Newey, D. W., \& Rosen, H. (1988). Estimating Vector Autoregression with Panel Data. Econometrica, 56(6), 1371-1395. http://dx.doi.org/10.2307/1913103

Im, K. S., Pesaran, M. H., \& Shin, Y. (2003). Testing for unit roots in heterogeneous panels. Journal of Econometrics, 115(1), 53-74. http://dx.doi.org/10.1016/S0304-4076(03)00092-7

Kakes, J., \& Sturm, J. E. (2002). Monetary policy and bank lending. Evidence from German banking groups. Journal of banking \& Finance, 26(11), 2077-2092. http://dx.doi.org/10.1016/S0378-4266(02)00200-5

Kashyap, A. K., \& Stein, J. C. (1994). Monetary Policy and Bank Lending. In G.N.M. Mankiw (ed.). Monetary Policy, Studies in Business Cycles (pp. 221-56), Chicago: University of Chicago Press.

Kashyap, A. K., \& Stein, J. C. (1995). The impact of monetary policy on bank balance Sheets. Carnegie-Rochester Conference Series on Public Policy, 42(1), 151-195. http://dx.doi.org/10.1016/0167-2231(95)00032-U

Leeper, E. M., Sims C. A., \& Zha, T. (1996). What does monetary policy do? Brookings Papers on Economic Activity, 27(2), 1-78. http://dx.doi.org/10.2307/2534619

Levin, A., Lin, C. F., \& Chu, C. S. J. (2002). Unit root tests in panel data: Asymptotic and finite-sample properties. Journal of Econometrics, 108(1), 1-24. http://dx.doi.org/10.1016/S0304-4076(01)00098-7

Love, I., \& Zicchino, L. (2006). Financial development and dynamic investment behavior: Evidence from Panel VAR. Quarterly Review of Economics and Finance, 46(2), 190-210. http://dx.doi.org/10.1016/j.qref.2005.11.007

Lown, C., \& Morgan, D. P. (2002). The Credit Cycle and the Business Cycle: New Findings Using the "Lost" Series on Commercial Credit Standards. Proceedings, Federal Reserve Bank of Chicago May: 282-307.

Lown, C., \& Morgan, D. P. (2006). The credit cycle and the business cycle: new findings from the Loan officer opinion survey. Journal of Money, Credit, and Banking, 38(6), 1575-1597. http://dx.doi.org/10.1353/mcb.2006.0086

Newey, W., \& West, K. (1994). Autocovariance lag selection in covariance matrix estimation. Review of Economic Studies, 61, 613-653. http://dx.doi.org/10.2307/2297912

Nickell, J. S. (1981). Biases in Dynamic Models with Fixed Effects. Econometrica, 49(6), 1417-26. http://dx.doi.org/ $10.2307 / 1911408$

Peek, J., \& Rosengren, E. S. (1995). The Capital Crunch: Neither a Borrower nor a Lender Be Source. Journal of Money, Credit and Banking, 27(3), 625-638. http://dx.doi.org/10.2307/2077739

Peek, J., \& Rosengren, E. S. (2013). The role of banks in the transmission of monetary policy. Federal reserve bank of Boston Public policy discussion papers No. 13-5.

Persyn, D., \& Westerlund, J. (2008). Error Correction Based cointegration Tests for Panel Data. Stata Journal, 8(2), $232-241$.

Pesaran, M. H., \& Shin, Y. (1998). Generalized Impulse Response Analysis in Linear Multivariate Models. Economics Letters, 58(1), 17-29. http://dx.doi.org/10.1016/S0165-1765(97)00214-0

Praet, P. (2014). Current issues in monetary policy. Speech by Peter Praet, Member of the Executive Board of the ECB, at the Peterson Institute for International Economics in Washington, DC, 9 December 2014.

Ramey, V. A. (1993). How Important is the Credit Channel in the Transmission of Monetary Policy. NBER Working Papers No. 4285.

Romer C., \& Romer, D. (1990). New Evidence on the Monetary Transmission Mechanism. Brookings Papers on Economic Activity, 21(1), 149-198. http://dx.doi.org/10.2307/2534527

Stein, J. (1998). An Adverse Selection Model of Bank Asset and Liability Management with Implications for the Transmission of Monetary Policy. The RAND Journal of Economics, 29(3), 466-486. http://dx.doi.org/10. 2307/2556100

Westerlund, J. (2007). Testing for Error Correction in Panel Data. Oxford Bulletin of Economics and Statistics, 69(6), 709748. http://dx.doi.org/10.1111/j.1468-0084.2007.00477.x

The article has been reviewed.

Received in July 2015; accepted in April, 2016. 